\title{
Ruoyun Bai, Staging Corruption: Chinese Television and Politics,
}

Hong Kong, Hong Kong University Press, 2015, 276 pp.

\section{Qian Gong}

\section{OpenEdition}

\section{Journals}

Electronic version

URL: http://journals.openedition.org/chinaperspectives/7500

DOI: $10.4000 /$ chinaperspectives. 7500

ISSN: 1996-4617

\section{Publisher}

Centre d'étude français sur la Chine contemporaine

Printed version

Date of publication: 1 December 2017

Number of pages: 67-68

ISSN: 2070-3449

\section{Electronic reference}

Qian Gong, "Ruoyun Bai, Staging Corruption: Chinese Television and Politics, », China Perspectives [Online], 2017/4 | 2017, Online since 01 December 2017, connection on 23 September 2020. URL http://journals.openedition.org/chinaperspectives/7500; DOI : https://doi.org/10.4000/ chinaperspectives.7500

This text was automatically generated on 23 September 2020 .

(c) All rights reserved 


\section{Ruoyun Bai, Staging Corruption: Chinese Television and Politics,}

Hong Kong, Hong Kong University Press, 2015, 276 pp.

\section{Qian Gong}

1 Reading Bai Ruoyun's book Staging Corruption: Chinese Television and Politics is even more fascinating while watching the 55-episode anti-corruption television drama In the Name of the People (Renmin de mingyi 人民的名义). This top-rating serial, created to spotlight $\mathrm{Xi}$ Jinping's crackdown on corruption, attracted millions of viewers. Many saw it as resurrecting a genre that had been in decline since 2004, when the government suddenly slapped a ban on the topic. The popularity of the serial serves as a footnote to how important the anticorruption genre has been in public discourse, as well as its continuing relevance to Chinese society today. One can't help but admire Bai's foresight in writing a book that illuminates the

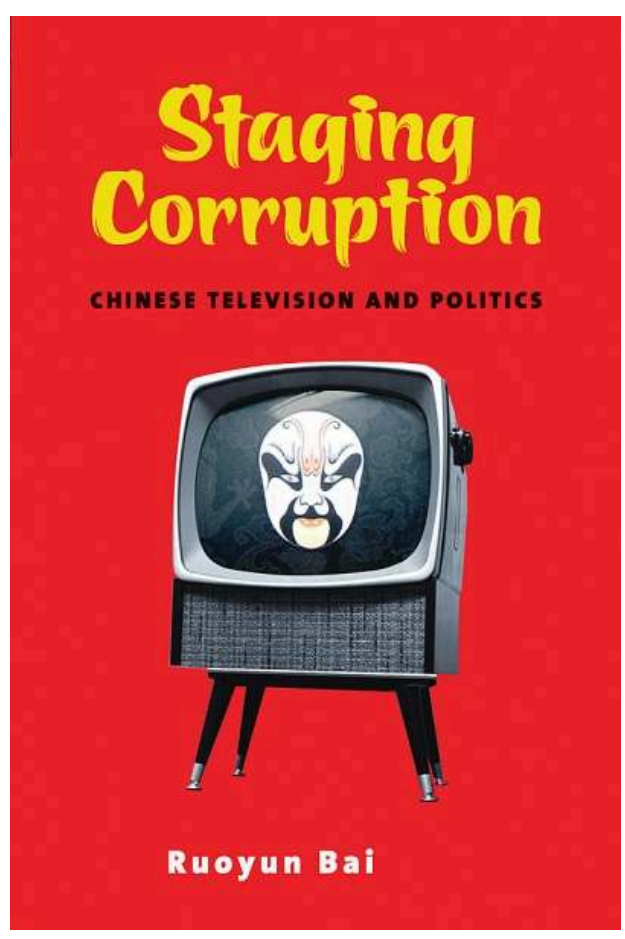
evolution of the anti-corruption genre and how this issue is embedded in Chinese society. Overall, I found Bai's account insightful, ingenious, and interesting.

2 Bai's book adopts an interesting point of entry into television studies in China. Unlike other books in the field, which often look at the various sub-genres, Bai's book has focused on one single genre, the anti-corruption television serials. This allows the author to thoroughly investigate the ebbs and flows of the TV drama serials in the 
complicated media ecology formed by media policy, censorship, financing, licensing, and content production in post-Mao China. However, Bai does not stop there. She takes on the sensitive topic of anti-corruption and examines the issue as "a site of ideological contestation" (p. 12). This enables her to probe broader social and political issues of great tension in post-socialist China, such as morality and governance. The book thus provides a rich and in-depth narrative about the transformation of contemporary Chinese society.

One of the main themes of the book is that the dominant feature of the post-Mao China media landscape is a "disjunctive media order." Bai uses the idea to describe the complex media system resulting from the interplay of political and economic forces. In the subsequent analysis, the book convincingly shows the impact of the contingent configuration of political and commercial interests on the features and fortunes of the anti-corruption genre. This allows for a more nuanced exploration of various logics at play within the TV drama as a mediated space. It is a welcome addition to the literature, which debunks some binary thinking about Chinese media as being only the product of state versus market, and provides insightful observations on this point.

Bai's ability to tease out the complex forces at play in the Chinese media industry is clear in Chapter Two, a case study on Heaven Above (Cangtian zaishang 苍天在上) (1995), the first anti-corruption TV drama serial. China Central Television (CCTV) commissioned a series on the hot topic of anti-corruption partly because of the Party's agenda on fighting corruption, but mostly out of a motivation to compete with the more commercialised provincial television stations. Subject to more stringent censorship, it was perhaps counterintuitive for CCTV to propose a politically risky project such as Heaven Above. However, Bai points out that CCTV is buffered from immediate commercial repercussions if a production ends up losing money. Its political capital can provide certain protection for its professionals in case the production also incurs official criticism. The tensions between the market and state cannot be resolved easily, but Bai observes that intellectuals, as cultural brokers, serve as mediators between the two forces. Sometimes the intellectuals are so skilful that they are actually able to produce "politically acceptable, market-sensitive, and even artistically gratifying" products.

In Chapter Three, Bai looks at the various factors that contributed to the rise and fall of the genre from 2000 to 2004. Here Bai provides systemic insights into the genre's transformation. Carried along with the anti-corruption campaign in 2000, corruption dramas faced less stringent political censorship. However, the real opportunity to flourish came when the government issued a ban on foreign dramas on prime-time TV, creating an immediate market for corruption dramas, now often financed by private investment. A synergy with the publishing industry also contributed to the boom in the genre. As the genre grew, the government was increasingly disturbed by the increasingly explicit crime and corruption content. In 2004, regulators put a ban on the entire genre, supposedly to maintaining social stability and restore moral order after these TV excesses.

6 Chapters Four to Six of the book focus on how the anti-corruption drama evolved into different genres over a span of two decades or so. Chapter Four examines the earlier productions of anti-corruption dramas, mostly melodramas. This type of serial often adopted a "good official" narrative, which originates in Confucianism. Initially popular with viewers, these dramas tied in closely with the CCP's anti-corruption campaign by 
putting the $\mathrm{CCP}$ at the centre of moral order. However, it increasingly came under attack from liberal-minded intellectuals for failing to address structural problems and for promoting "rule of man" instead of "rule of law." Intellectual interventions helped to disassociate corruption from the realm of morality in these dramas; yet ironically, the issue of corruption was rationalised and normalized in the process. According to Bai, a more dominant neoliberal discourse pre-empted critiques on the link between corruption and economic reform. Instead of delving into the systemic roots of corruption, anti-corruption dramas slid into cynicism.

Chapter Five deals with the development of new anti-corruption dramas in the 2000s. Bai astutely observes that despite the official ban on the anti-corruption topic on prime-time TV, the genre did not disappear but morphed into a "prototypical narrative of workplace politics" (p. 160). Corruption was removed from its contemporary context and relocated into an imagined "guanchang" (官场) culture, namely the realm of officialdom and all the dirty tricks associated with it. Taking the divergent forms of Qing court corruption, or contemporary satire on bureaucratic politics, cynics could view corruption as inherent and an unavoidable product of "guanchang" culture. Once again, corruption dramas failed to engage the political and economic roots of corruption, but served instead to further normalise it. Bai's impressive knowledge of Chinese literature, society, and politics helps lay bare the development of the genre in this stage, which could be rather hard to fathom otherwise.

Chapter Six gives a detailed analysis of a crowd-pleasing serial, Snail House (Wo Ju 蜗居), and its online responses to demonstrate how cynicism is at work full force in the production as well as the consumption of corruption drama. Snail House valorises a corrupt official, portraying him as capable and charismatic, a "desirable subject" who can survive in the competitive guanchang world. The online community seemed reluctant to see corruption as a moral issue, but was more ready to identify with the "neoliberal imperative to nurture and optimize the self" (p. 207). To Bai, the popularity of Snail House shows that the middle-class has largely lost the will and capacity to effectively critique corruption.

Bai's book is a remarkable addition to Chinese television studies. Readers will benefit not only from her in-depth research into the production and regulation of chinese television drama, but also from her erudite observations of the social, cultural, and political conditions of the fascinating anti-corruption genre. Her insightful analysis provides a fine example for students doing media and culture studies, as well as for the many in the general public who are fascinated by where China is headed.

\section{AUTHOR}

\section{QIAN GONG}

Qian Gong is a lecturer at the Faculty of Humanities of Curtin University, Perth, Australia (Q.Gong@exchange.curtin.edu.au). 